\title{
Ancient Mathematical Physics
}

\section{Paul TE Cusack*}

Saint John, Canada

Submission: January 11, 2018; Published: June 06, 2018

*Corresponding author: Paul TE Cusack, BScE, DULE, 1641 Sand y Point Rd, Saint John, NB, Canada E2K 5E8, Tel: (506) 214-3313;

Email: St-Michael@hotmail.com

Keywords: Ancient; Mathematical; Physics; Origin; Universe; Pyramids; Holy Grail; Egyptians; Hebrews; Modern science; Trigonometry; Quadratic equation; Decoding; Right triangle; Parabola; Stonehenge

\section{Introduction}

The author undertook an investigation in area of Mathematical Physics on the origin of the universe. My goal was to derive the universal equation - the Holy Grail of Physics for the last 300 years. The reason the pyramids and Stonehenge could not be interpreted is that modern science did not know as much physics as the Ancient Egyptians/Hebrews knew. From my blog on Physics, one can see all the physics that was lost to the ages. Stonehenge and the pyramids go together. The same people were behind both. They stand together.

I discovered in my work that the Egyptians already knew the universal energy equation. In fact it is embedded into the very geometry of the Pyramids, the highest achievement of their civilization. It is interesting that these ideas were known to other cultures who most likely learned it from Egyptians. They include: The Hebrews, the Scottish Jews, the Irish royalty, St Columbia, and the Mayans. Nostradamus even picked up on it in his quatrains.

In this brief paper, I intend to show what the ancient Egyptians knew and how it spread throughout the world.

\section{Egyptians Mathematics}

In my investigation of Physics, I derived the Cusack Universal Energy Equation C.U.E.E. It is a polynomial as follows:

$$
x^{2}-x-1=0
$$

This is a quadratic equation which was known to the Egyptian Mathematicians. It is solved by the well know equation:

$$
x=-b \pm \sqrt{\left[b^{2}-4 a c\right] / 2 a}
$$

\section{If one plugs $a=-1, b=c=-1$}

We get the solution of what is called the Golden Mean, or $\mathrm{x}=1.618$
The above polynomial is also expressed identically as

$$
\begin{gathered}
x=1 /[x-1] \\
x(x-1)=1 \\
x^{2}-x-1=0
\end{gathered}
$$

1.618 is the only number that solves this equation.

This, then is the U.C.E.E (Figure 1)

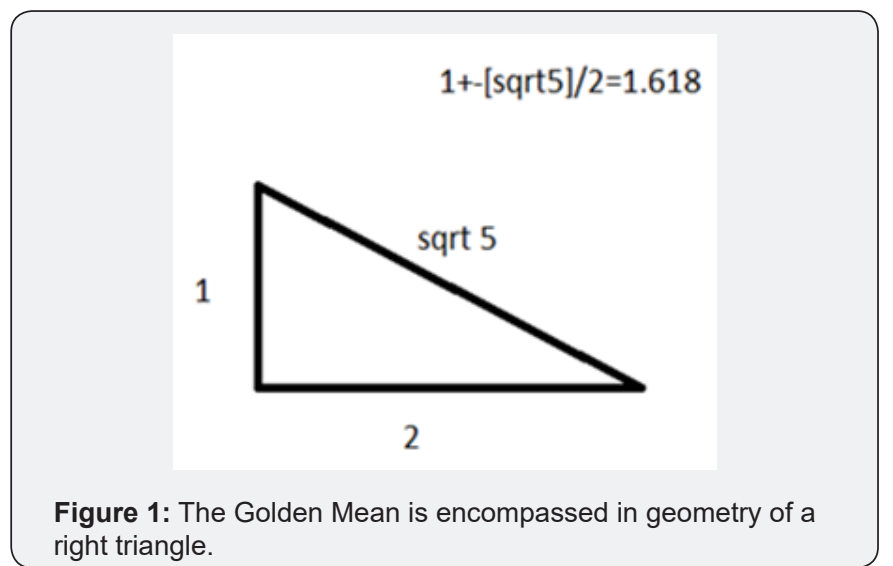

Note that the Golden Mean=1.618=1+/-[ sqrt 5]/2 This is simply the Quadratic Equation with $\mathrm{a}=1, \mathrm{~b}=\mathrm{c}=-1$

$$
x=-b \pm \sqrt{\left[-b^{2}-4 a c\right] / 2 a}=1.618=1 \pm \sqrt{5}
$$

The Egyptian Mathematicians also knew Trigonometry which relates the length of the sides of a right triangle by sine, cosine, and tangent. We know this because the geometry of the Pyramids requires knowledge of these facts. Also, they knew Pythagoras' Theorem $a^{\wedge} 2+b^{\wedge} 2=c^{\wedge} 2$ for a right triangle. Did the Egyptians know Calculus? Calculus is supposedly discovered by Sir Isaac Newton. But the knowledge of the C.U.E.E. is called a parabola. 


\section{Global Journal of Archaeology \& Anthropology}

The derivative involves the derivation of the rate of change of the function in another function.

The derivative of the polynomial $x^{2}-x-1=0$ is: $2 x-1=0$

I suggest the ancient Egyptian may have known calculus since they knew the quadratic equation and parabolas. Interesting that comets in Astronomy follow a parabola.

A quirk of calculus is that the derivative of the function $\mathrm{e}^{\wedge} \mathrm{x}=$ $\mathrm{e}^{\wedge} \mathrm{x}$. Another quirk is that the derivative of the $\sin \mathrm{x}=\cos \mathrm{x}$. These functions are paramount in the C.U.E.E as $y=y^{\prime}$ or the derivative equals the function. The universe is described by the cosine in series form. It is the famous Kepler function: E-esinE=M

This is a parabola too.

\section{Egyptian Architecture}

In the great Pyramid, the trigonometry involves the golden mean. Someone has produced this interesting graphic: (Note the golden mean) (Figure 2). Now, in "Decoding the Pyramids", the author provides a plan view to scale of the Pyramids at Giza. They are laid out in plan view to follow the C.U.E >E. (Figures 3-5)

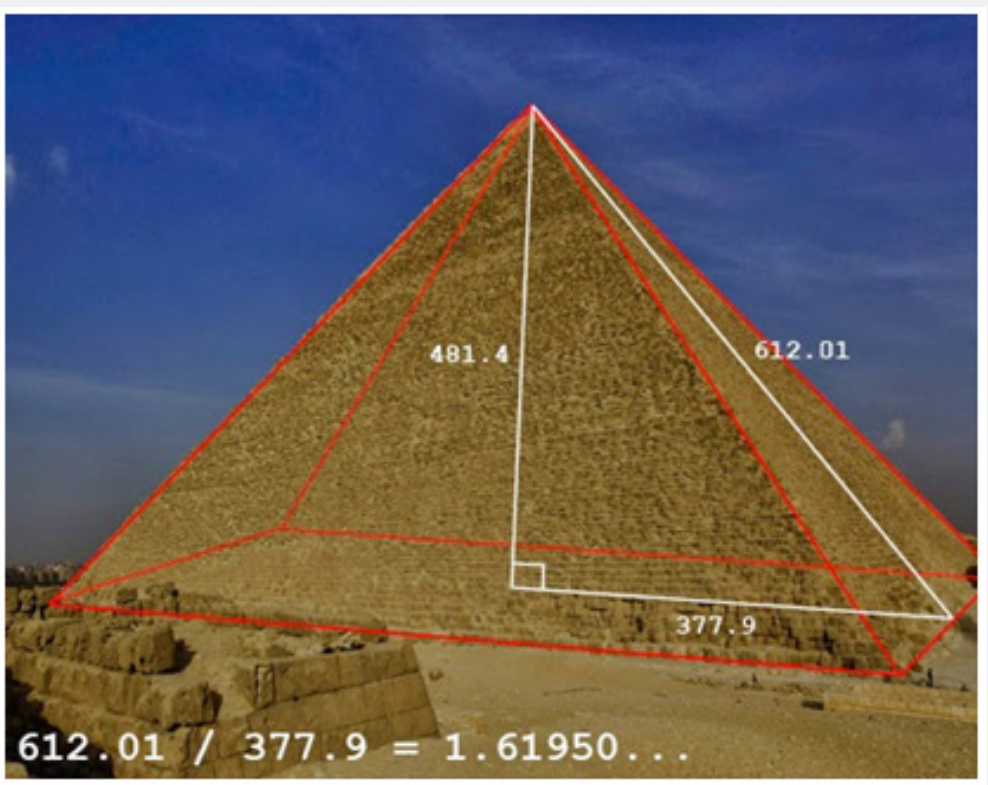

Figure 2: From Internet: Images of the Pyramids.

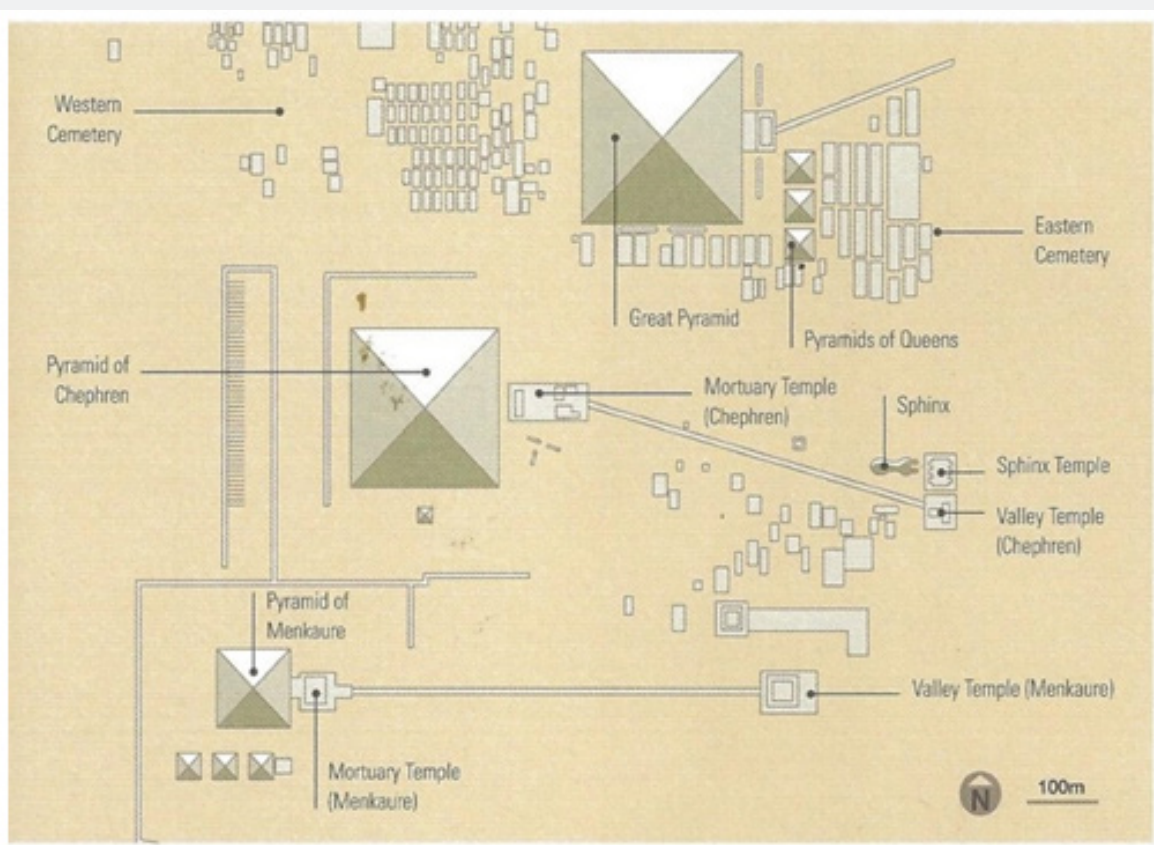

Figure 3: "Decoding the Pyramids "J. DE DeSalvo Ivy Press 2008 pg 15. 


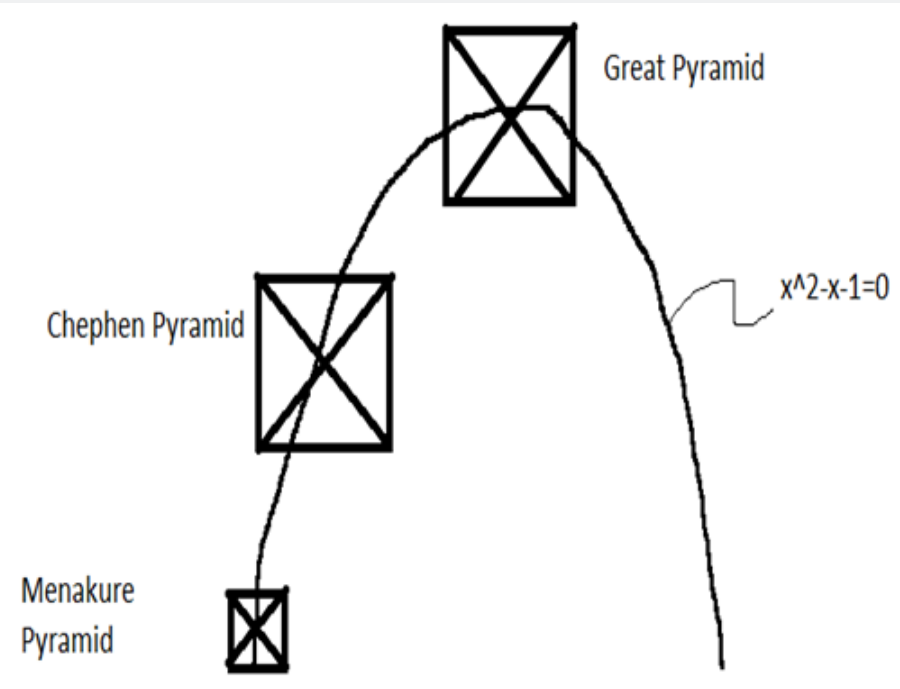

Figure 4: spacing of the pyramids.

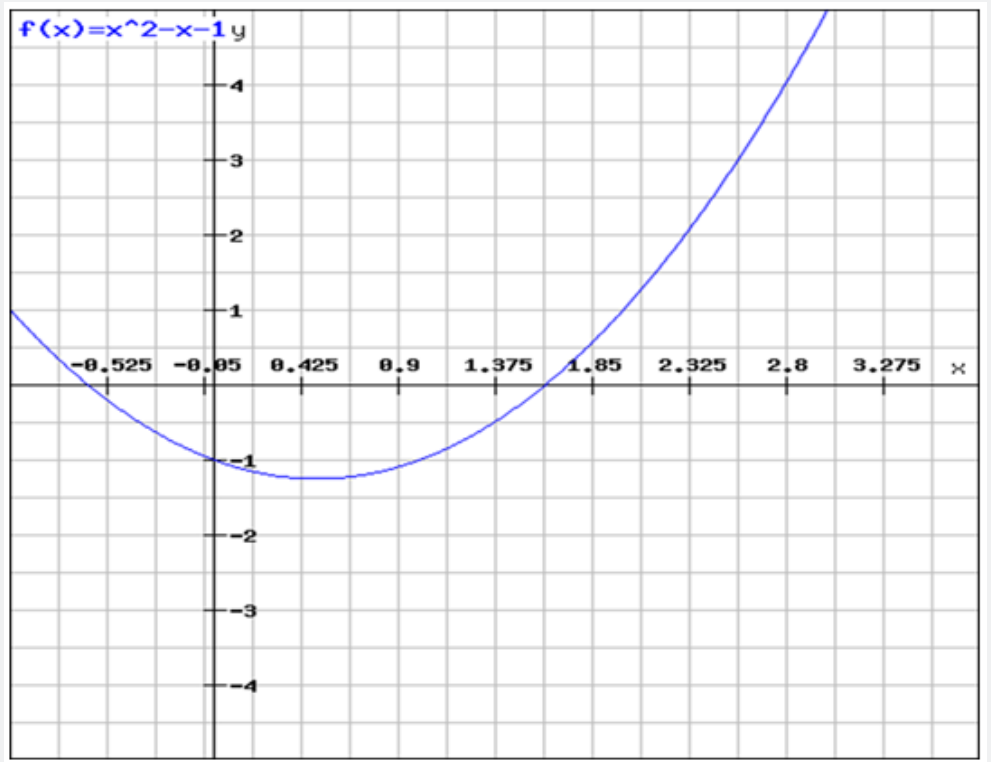

Figure 5: Even more interesting is that if time is the $\mathrm{x}$ axis, there is a spacing of the pyramids that lead to the following.

If you lay one over the other, for the Great Pyramid, $t=0.9$ or $(900-500=400 \mathrm{BC})$ years before Christ. $\mathrm{Y}=1=$ =nergy. Alexander the Great conquered Egypt in this period. Ptolomy was made Pharaoh. Doing the same for the Chephren Pyramid is at 1.85 (1850-500)=1350 King Tut became Pharaoh. The third pyramid lies at 2.5375 or 2037 BC. end of the old Kingdom.

Continuing, the area of the great Pyramid is 13 acres. Without going into all the Mathematical Physics (which is available on my blog Astrotheology the Missing Link), there are 13 cycles of time in the universe. Finally, according to the scale drawing, the Pyramids have the length of the legs of $1,2,2$. This embodies the golden mean: $1+2+2=5, \& 1, \& 2$ from above. The Pyramids are shown in "Decoding the Pyramids", to lie at 30 longitude and 30 degrees latitude. From Pythagoras' Theorem, the hypotenuse is 4.242. This is very close to $\mathrm{Pi}-\mathrm{e}=3.1415-2.71828=0.4233=$ cuz This is a physical constant in our universe, not revealed until now. It was sometimes called Einstein's constant.

\section{Israelites}

It is an Historical fact that the Hebrews spent 450 years in Egypt before being lead out of slavery by Moses. I think they took this universal geometric knowledge with them that they must have learned in Egypt (Figure 6). 


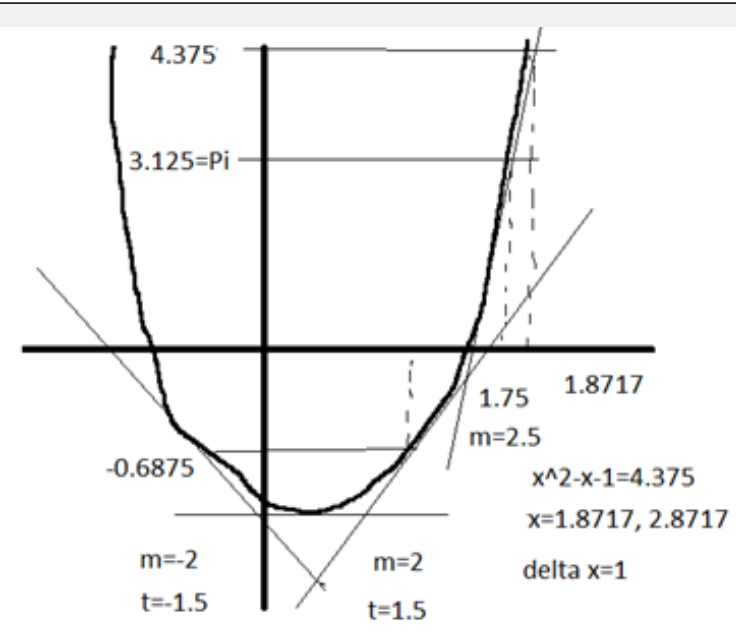

Figure 6: The arc of the covenant so well described in the Hebrew Scriptures, has the dimensions, $1.5 \times 1.5 \times 2.5$.

The Ark of the Covenant is $1.5 \times 1.5 \times 2.5$

The slope $\mathrm{m}=2,-2$ at $\mathrm{t}=1.5,-1.5$

$\mathrm{m}=2.5$ at $\mathrm{t}=3.125$ or $\sim P^{i}$

The Pyramids encode the Energy Parabola known to the ancients. This indicates the Egyptian Mathematicians knew elementary calculus. The slopes of those tangents are derivatives of the C.U.E.E

\section{Stonehenge}

The people who built the Pyramids also built Stonehenge. Genetic genealogy is showing that the Scots were Israelites. Stonehenge also embodies the golden mean in the ration of the stone circles 2,2,1 - the same as the Egyptian Pyramid bases.

The Longitude of Stonehenge is 1.8 degrees and the Latitude is 51.17 degrees. The slope on the Great Pyramid is 51.5 degrees. That is a 31.8 (Human Perception =31.8 Hz) by $21.17(21.17$ ${ }^{\wedge} 2=4.482 \sim$ Mass of Universe $\left.=4.486\right) 18$ is the sum of the Potential Energy plus the Kinetic Energy (Figure 7).

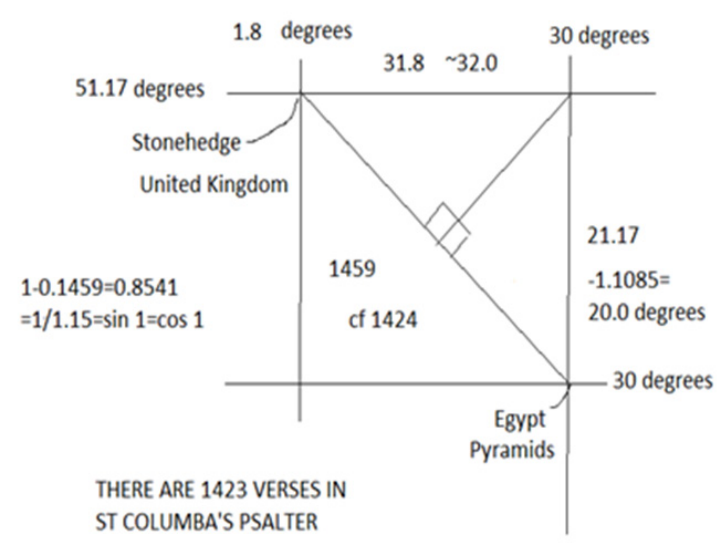

Figure 7: Reference: Ancient Measurement of the Circumference of the Earth.
Ancient metrological tables state that the Philetairic or Ptolemaic royal cubit (which is the Babylonian-Egyptian royal cubit according to Boeckh's terminology) is $9 / 5$ of the Roman foot, so that the figure of Eratosthenes comes to be the usual figure of 75 Roman miles to the degree.

But several authors of the Roman period mention a degree of 700 stadia. This degree value should not be confused with that of Eratosthenes and is based on a stadion of 300 royal cubits of the Pharaonic period; these two points have been made by Letronne. I have reported that the correct Egyptian royal cubit was $525 \mathrm{~mm}$, but it was at times computed as $524 \mathrm{~mm}$ and at times as $\mathrm{mm}$. Assuming a cubit of $525 \mathrm{~mm}$. the degree would be 110,250 , and assuming a cubit of $526.3 \mathrm{~mm}$. It would be 110 , It is easy to see why the figure of 700 stadia to the degree was chosen: it well fits the pattern of septenary reckoning in the Egyptian royal cubit. But the length of the degree at latitude $30^{\circ}$, the latitude of the pyramids and of the beginning of the Delta, is $110,849 \mathrm{~mm}$. At the southern limit of the country, which is at latitude $24^{\circ}$, the degree 110,750m? Hence, it seems that in Egypt, for the sake of a convenient reckoning there was adopted a value that it slightly in defect. Perhaps the figure was chosen because it was convenient and the methods of observation used did not allow determining any error in it. This figure may have had great importance in convincing the ancients that the degree was shorter in Egypt than at latitude $36^{\circ}$ (Figure 8). Cosine $\mathrm{x}$ is the universal equation. Stonehenge is the "throne of God." The Pyramids of Egypt are sqrt $1424=0.858=0.86$ away from the Throne of God.

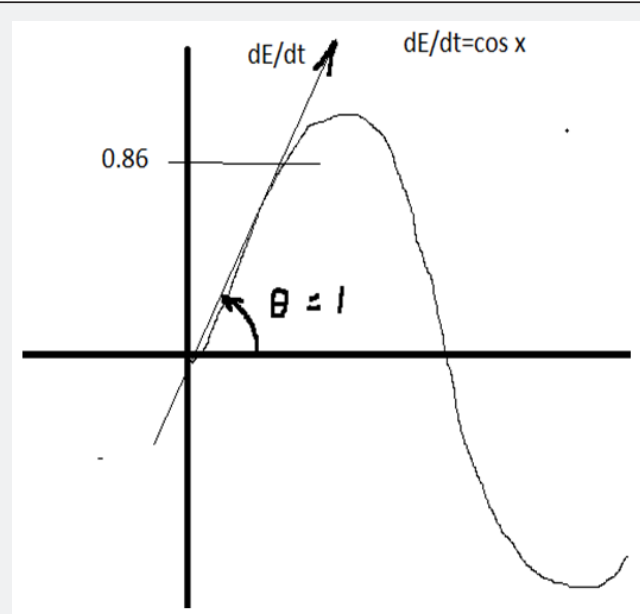

Figure 8: Stonehenge is the "throne of God.

\section{From the Christian Community Bible}

There, in heaven, was a throne and one sitting on it. He who sat there looked like jasper and carnelian and round the throne was a rainbow resembling an emerald. In a circle around the throne are twenty-four thrones and seated on these are twenty-elders, dressed in white clothes, with golden crowns on their heads. 5 Flashes of lightning come forth from the throne, with voices and thunderclaps. Seven flaming torches burn before the throne; these are the seven spirits of God (Figure 9). 


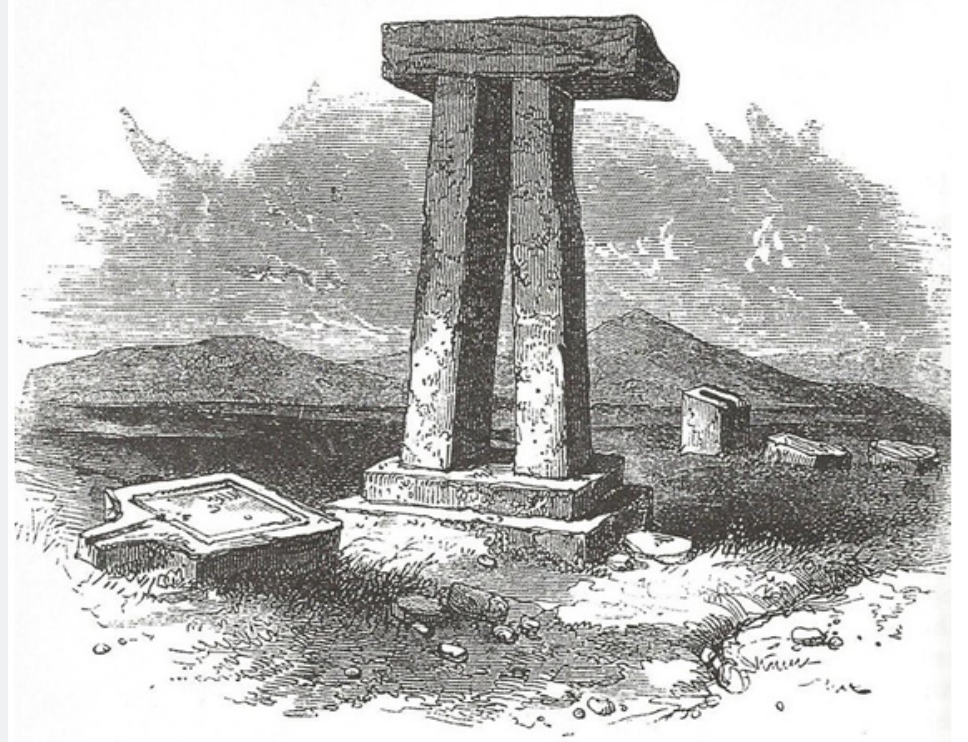

Figure 9: Before the throne there is a platform, transparent like crystal. Around and beside the throne stand four living creatures, full of eyes, both in front and behind.

The stone lintels for the greek letter pi=3.14 which figures into the universal energy equation.5 X $3.14=15.70$ $1-0.1570=0.8430=\operatorname{SIN} 1=\operatorname{COS} 1$

Interior Stones $=$ Total Energy $=$ P.E + K.E $=18$

From Stonehenge Complete Chippendale C, Cornell U Press, 1983

\section{From Internet: Images of Stonehenge}

The individual stones at Stonehenge are $10.5 \times 3.5 \times 2.75$ That is $42 / 4 \times 14 / 4 \times 11 / 4$

$\mathrm{dM} / \mathrm{dt} * \mathrm{M}$ rho/Erho=1/G 2x 3/4=1/.666 (Revelation 13)
$42=\mathrm{Pi}-\mathrm{e}=\mathrm{cuz} ; 14-100=86=\sin 1=\cos 1 ; 9=\mathrm{c}^{\wedge} 2$ all physical constants of the universe. The stones are 13.5 feet high. 13.5$100=86.6,=\sin 1=\cos 1$

There are 30 stones on the perimeter. $30 / 4=7.51 / 7.5=0.1334$ this is distance $\mathrm{s}$ in Physics

The Heel Stone is almost 85 feet outside the causeway ( $\sin$ $1=\cos 1=0.8415)$. The heel stone is almost 16 feet high $(0.1585$ $1=0.8415$ )

From Stonehedge Complete Chippendale C, Cornell U Press 1983 (Figure 10).

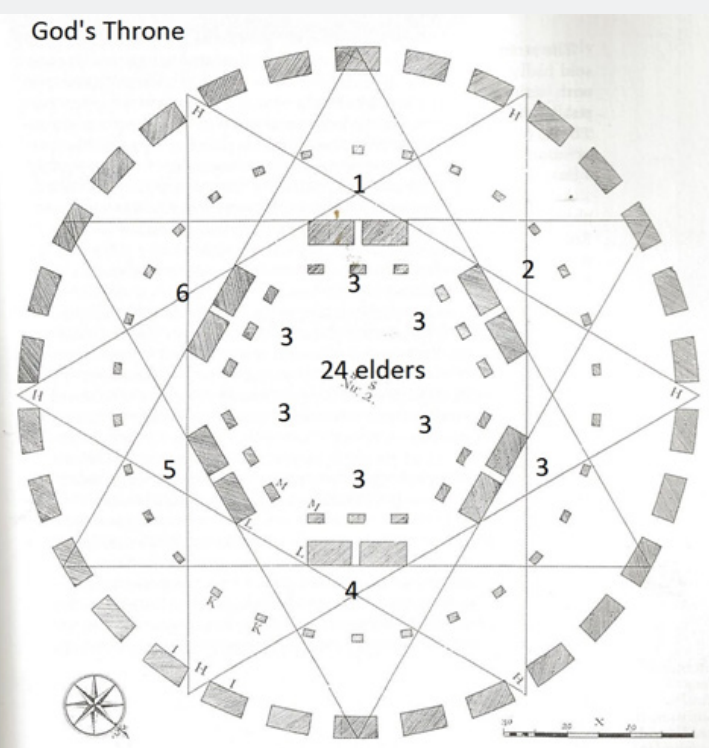

Figure 10: This is the same as the bases of the Great Pyramids in Egypt. 
The relative radius measures are $45-65=20 ; 65-85=20$; 85 $95=10$ or 2, 2, 1 . This is the same as the bases of the Great Pyramids in Egypt. The Mass of the universe; the gravitational constant; the meeting of $\sin 1$ radian $=\cos 1$ radian $=0.8415$. Of course, the Winter Solstice- final date of December 21 is embodied as well. JESUS came at the bottom of the parabola or where the derivative of the C.U.E.E. $=0(2 \mathrm{t}-1=0)$ Each division of the $\mathrm{x}$ axis is 1000 years per decimal Jesus was born in 3BC at the base of the parabola.
The stone circles of the British Isles were mostly constructed between 2500-1600 Bc. The Pyramids in Egypt, as above, from 2037 -400BC. Moses left Egypt in 1800 BC. So the stone circles predate the pyramids of Egypt. But Stonehenge in the form of its inner circle, which relate it to the Egyptian Pyramids, was constructed in around 200-1550 BC. So, that is only 37 years after the Pyramids were built we see the golden mean in Stonehenge (Figure 11).

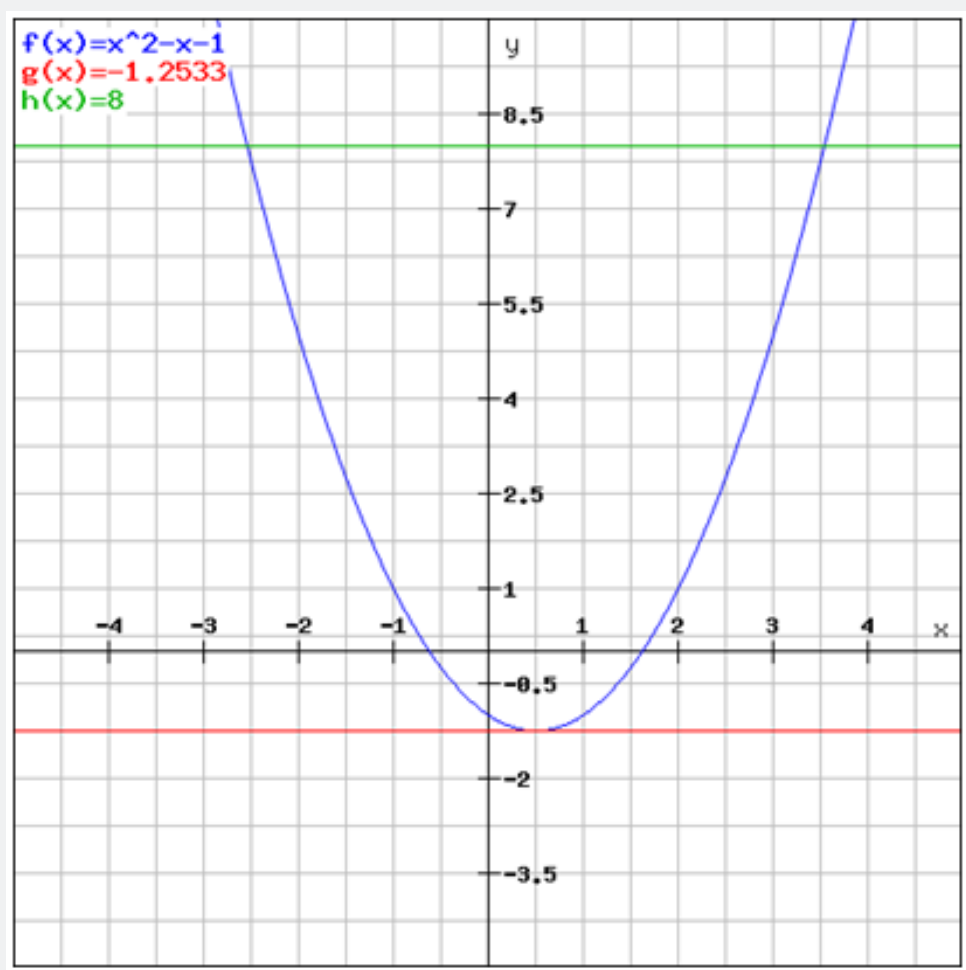

Figure 11: ST Columba's PSALTER.

\section{St Columba's Psalter}

It is well known "Ledge" that the Spaniard Mileisus (Mil Espania=Soldier of Spain) was said to have desired to go to Ireland that he could see on the horizon of the seas from Northern Spain. He didn't make it, but three of his boys (Heber, Hermon, and Ir).. Mileisus was known to have travelled to Jewish Khazaria (Kazakhstan) and to Egypt. I think he was of royal Israelite blood. His 3 boys formed the Irish Royalty as they divided the island amongst themselves. . Interesting that the O'Brien clan - the Irish Royalty show RL21-L226 Y DNA. Now St Columba, the patron of Ireland and Scottland was known to be of Royal Blood. He has his famous Psalter of Prayer book. There are 1423 verses in his Psalter. The conjugate of $0.1423-1=0.8577$. This is where $\sin 1=\cos 1$. It is an important factor iun the "new" Physics. See Astrotheology the Missing Link.

There are 150 Psalms in the Bible. His Psalter held in the gold box holds the key. His Psalter runs from Psalm 30v 10 to Psalm $105 \mathrm{v}$ 13. The middle verse is Psalm 72 v 10. St Columba's Psalter runs from Psalm 30: 10 - 105:13

\section{The middle verse is Psalm 72 v 10}

For my enemies speak ill of me; awaiting my death they set plans.

a. They say, "God has forsaken him; let us pursue and seize him, for no one will rescue him."

b. O God, be not far from me; my God, make haste to help me!

c. Let my accusers be destroyed in shame; let those who seek my ruin be covered with disgrace and scorn.

d. Then I may trust in you and praise you.

e. My lips will proclaim your intervention and tell of your salvation all day, little though it is what I can understand.

f. I will come to your strength, O Lord, and announce your justice, yours alone.

g. You have taught me from my youth and until now I proclaim your marvels. 
h. When I grow old and gray, do not leave me, 0 God; give me time to declare your might, your power to all generations to come.

i. Your justice, 0 God, reaches to heaven; you have done great things. Who is like you, $\mathrm{O}$ God?

j. Many have been my hardships and misery, but once more you come to revive me; from the depths of the earth you will bring me up again.

k. You will restore me and comfort me again. l. I will praise you with the harp, for your faithfulness, 0 my God; I will sing your praise with the lyre, 0 Holy One of Israel.

m. My lips will rejoice, and my soul, too, which you have rescued.

n. I will recall your intervention the whole day long, "Yes, those who sought to do me harm have been confused and put to shame."From The Stone Circles of The British Isles by Burl, A Yale U Press 1976 (Figure 12).

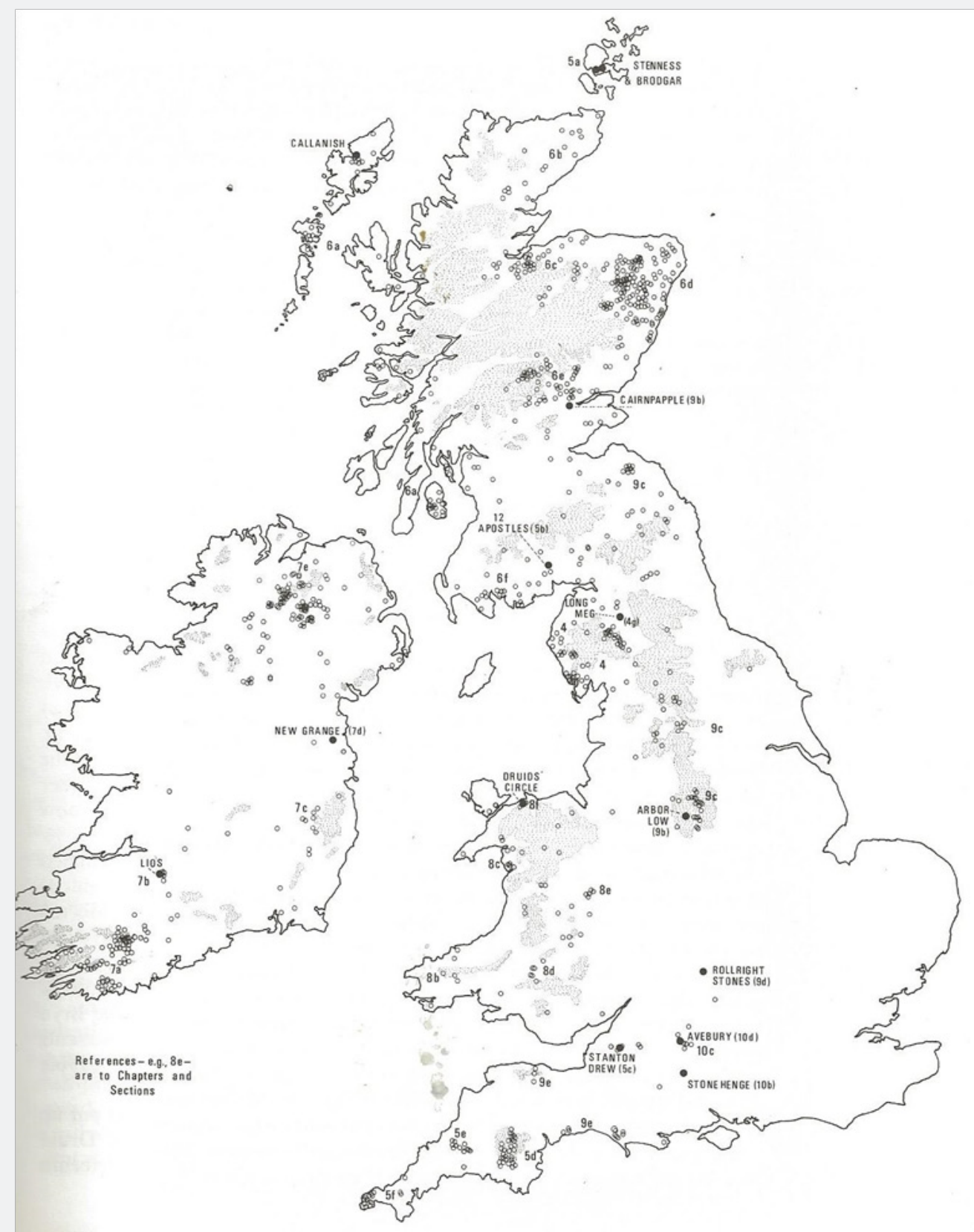

ig. 1. The Distribution of Stone Circles in the British Isles. Important sites are named. Numbers and letters efer to Chapters and Sections in the text

Figure 12: Distribution of Israelites in Ireland, Scottland and Wales. 
This Psalm is about the Second Messiah, Moshiach Ben Eprhaim - a son of Joseph (Genesis 48:5). Joseph you recall was second to the pharaoh in Egypt before the Israelites left Egypt for the the Sinai desert. Nostradamus even writes about the End Times. If one reverses Psalm 71 v10 to Century 10 Quatrain 72, we have: So Nostradamus 10 v 72 is about the Great Monarch's rise: $X 72$.

L'an mil neuf cens nonante neuf sept mois

Du ciel viendra vn grand Roy d'effrayeur

Resusciter le grand Roy d'Angolmois (KING OF ANGEL/ MONTH=SEPT 29= - ST MICHAEL= FRANCE),

Auant apres Mars regner par bon heur.

The year 1999, seventh month, [ASTEROIDS EARTH COLLISION]

From the sky will come a great King of Terror: [WRATH OF GOD]

To bring back to life the great King of the Mongols,

Before and after Mars to reign by good luck.[ASTEROIDS CAN'T BE SEEN NEAR SUN]

This work is licensed under Creative Commons Attribution 4.0 License

DOI: 10.19080/GJAA.2018.04.555639
An article appeared on CNN in July 1999 as follows: "Scientists reduce odds of Earth-asteroid collision" July 28, 1999 Web posted at: 9:36 a.m. EDT (1336 GMT). Incidentally, Jesis came at the bottom or minimum of the parabola described above.

\section{Mayan Pyramids}

Finally, there are Mormons claim the North American Indians were from the tribe of Manesseh. Manessah was, of course the twin brother of Ephraim, bith sons of Joseph. They were born in Egypt. The Mayan Pyramid has a final date of December 21, 2012. But the calendar is off by $3 \mathrm{BC}$ since Jesus was born in $3 \mathrm{BC}$. That would make the end date to be December 21, 2015 instead of 2012. The Mayans may indeed have also had the Egyptian secretes of the C.U.E.E.

\section{Conclusion}

So, Egyptian Mathematicians knew more Physics than we knew until now. It spread around the world from Stone Henge to Mexico through the Israelites. Perhaps there are other secrets to be unveiled in the geometry of the great Pyramids of Egypt? The lesson to be learned is that humanity must protect and maintain knowledge or be forced to start over again and again. What was lost in the library of Alexandria?

\section{Your next submission with Juniper Publishers will reach you the below assets}

- Quality Editorial service

- Swift Peer Review

- Reprints availability

- E-prints Service

- Manuscript Podcast for convenient understanding

- Global attainment for your research

- Manuscript accessibility in different formats

( Pdf, E-pub, Full Text, Audio)

- Unceasing customer service

Track the below URL for one-step submission https://juniperpublishers.com/online-submission.php 